\title{
PELATIHAN SNI SO 17025: 2008 BAGI TENAGA LABORATORIUM
}

\author{
I Made Gunamantha ${ }^{1, *}$, Ni Wayan Yuningrat ${ }^{2}$, Ni Putu Sri Ayuni ${ }^{3}$ \\ 1 Jurusan Analis Kimia. Universitas Pendidikan Ganesha, Indonesia \\ 2 Jurusan Analis Kimia. Universitas Pendidikan Ganesha, Indonesia \\ 3 Jurusan Analis Kimia. Universitas Pendidikan Ganesha, Indonesia
}

\begin{abstract}
Abstrak
Laboratorium adalah penyedia jasa yang bergerak di bidang pengujian mutu wajib didukung oleh tenaga teknis yang kompeten. Tenaga Penguji Laboratorium memiliki salah satu tugas melayani masyarakat. Masyarakat menghendaki mutu hasil pengujian laboratorium terus ditingkatkan seiring dengan kemajuan ilmu pengetahuan dan teknologi. Tenaga penguji laboratorium harus senantiasa mengembangkan diri dalam menjawab kebutuhan masyarakat akan adanya jaminan mutu terhadap hasil pengujian laboratorium dan tuntutan diberikan pelayanan prima. Seiring dengan perkembangan dan kemajuan dunia, tuntutan standardisasi mutu pelayanan laboratorium tidak dapat dielakkan lagi. Pada saat ini, SNI 17025:2008 merupakan sebuah standar yang sangat populer di kalangan praktisi laboratorium. SNI 17025:2008 adalah persyaratan kompetensi laboratorium. Namun demikian, masih banyak praktisi laboratorium yang kurang memahami SNI 17025:2008 karena terbatasnya kesempatan dan mahalnya biaya pelatihan. Pengabdian masyarakat ini dimaksudkan untuk memberikan pelatihan tentang pemahaman sistem manajemen mutu laboratorium SNI ISO 17025: 2008 bagi tenaga laboratorium pengujian. Hasil pelatihan ini menunjukkan bahwa adanya peningkatan pemahama, wawasan, dan pengalaman peserta; membantu peserta untuk melakukan gap analisis antara kondisi yang ada di laboratoriumnya saat ini dengan tuntutan persyarata ISO 17025; dan melengkapi kompetensi peserta sebagai tenaga laboratorium pengujian.

\author{
Keywords: \\ laboratorium, mutu, \\ tenaga penguji, \\ pelatihan
}

\section{Pendahuluan}

Saat ini manusia hidup di era kualitas (mutu) (Juran and Godgrey, 1999). Mutu diukur, dianalisis, dan dibahas dimana-mana. Mutu menjadi tuntutan dari berbagai pihak baik sebagai individu, perusahaan, maupun kelompok masyarakat. Implikasinya adalah mutu akan menentukan keberhasilan bagi penyedia produk atau layanan. Dengan demikian, organisasi harus terus menerus meningkatkan mutu produk atau layanannya agar sesuai dengan keinginan pelanggan. Setiap instansi atau perusahaan yang ingin meningkatkan kinerja dan kompetensi harus memberikan perhatian penuh pada mutu produk atau jasa yang dihasilkannnya. Mutu yang baik tersebut hanya bisa dihasilkan melalui proses manajemen organisasi yang baik pula, diantaranya dengan memiliki sistem atau program-program mutu (Donnel et al., 2010). Salah satu strategi organisasi untuk meningkatkan sistem manajemen mutunya adalah dengan mengadopsi standar ISO 9001 (Schlickman, 2003).

Standar ISO 9001 yang hingga saat ini masih berlaku adalah ISO 9001 tahun 2008 atau di Indonesia diadopsi sebagai SNI ISO 9001: 2008. Standar ini dapat digunakan oleh pihak internal dan eksternal termasuk lembaga sertifikasi untuk menilai kemampuan organisasi dalam memenuhi persyaratan pelanggan, regulasi, dan peraturan perundangan yang berlaku untuk produk dan persyaratan organisasi sendiri (BSN, 2008). Selain ISO 9001, banyak lagi jenis standar yang diterbitkan oleh ISO sebagai lembaga Organisasi Internasional untuk Standarisasi (The International Organization for Standarization), seperti ISO 14001 (Sistem Manajemen Lingkungan), OHSAS 18001 (Sistem Manajemen Keselamatan dan Kesehatan Kerja), ISO 17025 (Sistem Manajemen Mutu Laboratorium), dan lain sebagainya. Sebagaimana SNI ISO 9001: 2008, beberapa nstandar ISO yang lain juga diadopsi sebagai bahan penyusunan standar bertaraf nasional berupa SNI (standar nasional Indonesia) yang disusun dan ditetapkan oleh BSN (Badan Standarisasi Nasional). Misalkan SNI ISO 17025:2008 (persyaratan umum 
kompetensi laboratorium pengujian dan laboratorium kalibrasi) merupakan adopsi indentik dari ISO 17025: 2008 (Hadi, 2007).

Sebagaimana organisasi-organisasi di luar laboratorium, laboratorium pengujian dan kalibrasi juga dituntut untuk menunjukkan hasil pengujian atau kalibrasi yang bermutu. Menurut BSN (2008), hasil uji dapat dikatakan mempunyai mutu yang tinggi apabila (1) Data hasil uji tersebut dapat memuaskan pelanggan dengan tetap mempertimbangkan aspek teknis sehingga presisi dan akurasi atau ketepatan dan ketelitian yang tinggi dapat dicapai dan (2) data harus mempunyai kemampu-telusuran pengukuran dan terdokumentasi, sehingga dapat dilaporkan secara ilmiah maupun hukum. Dalam upaya untuk mencapai mutu data hasil uji lab yang tinggi maka, (1) seluruh metode dan prosedur operasional laboratorium harus terpadu, (2) keterpaduan tsb meliputi dari perencanaan pengambilan contoh uji, penanganan, pengujian, sampai pemberian laporan hasil uji ke pelanggan, dan (3) laboratorium harus selalu mengembangkan dan menerapkan pengendalian mutu (quality control) dan jaminan mutu (quality assurance) (Hadi, 2007).

Pada saat ini, SNI 17025:2008 merupakan sebuah standar yang sangat populer di kalangan praktisi laboratorium. SNI 17025:2008 adalah persyaratan kompetensi laboratorium. Suatu laboratorium dapat dinyatakan sebagai laboratorium yang kompeten apabila laboratorium tersebut telah diakreditasi oleh badan akreditasi nasional, yaitu Komite Akreditasi Nasional (KAN). KAN mengakui kompetensi laboratorium pengujian dan laboratorium kalibrasi menggunakan standar ISO/IEC 17025 sebagai dasar acuannya. Laboratorium terakreditasi berarti bahwa laboratorium tersebut mampu dalam melakukan pengujian dengan metode dan prosedur pengujian tertentu dengan benar dan akurat. Sehingga akreditasi memberikan jaminan kemampuan laboratorium hanya pada kemampuan pengujian dalam lingkup yang diakreditasi (Huber, 2009).

\section{Metode}

Dua metode utama digunakan dalam pelatihan ini yaitu ceramah dan diskusi dan praktek penyusunan standar operasional prosedur. Melalui ceramah dan diskusi diharakan peserta mampu memahami klausal-klausal dalam ISO 17025. Adapun setelah praktek diharapkan peserta menyusun dokumen dan menerapkan sistem manajemen mutu laboratorium ISO 17025.

Khalayak sasaran strategis pelaksanaan P2M ini adalah tenaga laboratorium pada instansi pemerintah/suasta di Bali khususnya, yang merupakan anggota Himpunan Profesi Analis Kimia Profinsi Bali. Pelatihan diikuti oleh 34 orang yang berasal dari berbagai instansi baik yang ada di Bali maupun di Luar Bali. Tercatat dalam agenda kami peserta yang mengikuti pelatihan ini diantaranya ada yang bersal dari Universitas Negeri Mataram sebanyak 2 (dua) orang dan dari Institut Teknologi Sepuluh Nopember 1 (satu) orang sisanya dari instansi pemerintah dan suasta yang ada di Bali.

\section{Hasil Dan Pembahasan}

Registrasi peserta dilakukan dari pukul 08.00 - 0.9.00. Peserta berasal dari berbagai instansi pemerintah maupun suasta. Pelatihan diikuti oleh 32 orang peserta diantara 2 (dua) orang berasal dari Universitas Negeri Mataram, 1 (satu) orang dari Institut Teknologi Sepuluh Nopember, dan sisanya berasal dari instansi pemerintah maupun suasta yang ada di Bali. Acara dibuka pada pukul 08.30 oleh ketua pelaksana (Dr. I Made Gunamantha) mewakili ketua Lembaga Pengabdian Kepada Masyarakat Undiksha (Prof. Dr. Ketut Suma). Dalam sambutannya ketua panitia berharap bahwa peserta dapat meningkatkan profesionalismenya sebagai tenaga laboratorium pengujian secara berkelanjutan. Disamping itu, beliau juga menjelaskan latar belakang dilakukannya kegiatan ini dan manfaat lain yang diharapkan dapat diperoleh terkait dengan kerjasama antara Lembaga Pengabdian Kepada Masyarakat (LPM) dan Himpuni Profesi Analis Kimia Indonesia Regional Bali Nusra di masa mendatang.

Peserta tampak antusias menjalani kegiatan pelatihan. Sebagian besar peserta tidak memiliki dasar sistem manajemen mutu. Namun kesungguhan peserta dalam mengikuti pelatihan menghasilkan pemahaman yang baik tentang pemanfaatan sistem manajemen mutu laboratorium ISO 17025: 2008. Walaupun semua peserta beerja sebagai tenaga laboratorium, namun mereka berasal dari beragam institusi. Diantaran sebagai tenaga laboratorium kesehatan 18 (empat belas) orang, laboratorium kantor/badan lingkungan hidup 5 (lima) orang, pranata laboratorium pendidikan empat (4) orang, dan dari sektor lainnya 7 (tujuh) orang.

Pada pelatihan kali ini hanya difokuskan pada pengenalan dan interpretasi ISO/IEC 17025:2008 (persyaratan manajemen), pengenalan dan interpretasi ISO/IEC 17025: 2008 (persyaratan teknis), dan pengenalan pembuatan dokumen mutu laboratorium khususnya manual mutu dan standar operasional prosedur. Selain memberikan pemahaman melalui ceramah dan diskusi, peserta secara berkelompok juga 
diminta untuk mencermati dan membuat dokumen mutu. Pada pertemuan ke-2, peserta juga diperkenalkan dengan ISO 15189 "Laboratorium Medis - Persyaratan Mutu dan Kompetensi", yang digunakan sebagai dasar pengakuan kompetensi laboratorium medik.

Selama pelatihan, peserta secara aktif bertanya mengenai hal-hal yang tidak dipahami pada saat pengajar/instruktur memberikan pelajaran. Pada akhir penyajian, peserta diberkan pertanyaan pilihan ganda untuk mengukur sejauhmana pemahaman peserta terhadap materi pelatihan yang diberikan. Demikian pula, peserta diminta untuk membuat SOP secara berkelompok. Hal ini menjadi daya tarik sendiri bagi peserta untuk dieksplorasi. Kegiatan diakhiri dengan foto bersama sebagaimana ditunjukkan pada Gambar 1. Namun demikian, tidak semua perserta dapat mengikuti acara penutupan ini.

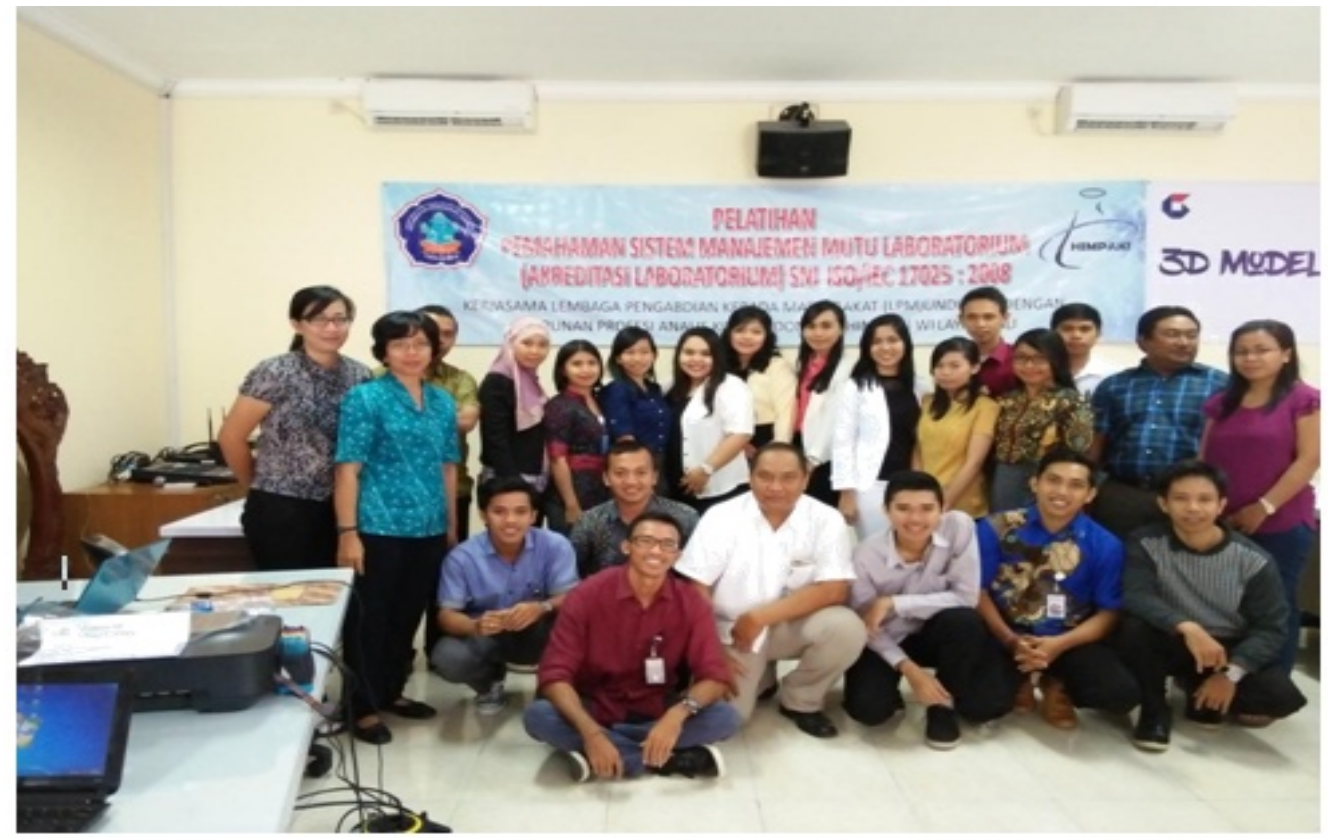

Gambar 1. Sebagian dari Peserta Pelatihan

Semua materi pelatihan diberikan dalam bentuk teori dan pengenalan dokumen mutu serta cara pengisian daftar isian permohonan akreditasi SNI 19-17025. Adapun praktek pembuatan SOP dilakukan di instansi masing-masing, namun hasilnya dikirim via email dan diberikan masukan oleh penyaji. Selain dapat meningkatkan pemahaman peserta terhadap persyaratan ISO 17025, pelatihan ini juga telah memberikan manfaat lain yakni sebagai wahana tukar informasi dan pengalaman terkait dengan sejauhmana sistem ini telah diadopsi di instansi masing-masing. Dengan memperhatikan latar belakang sebagai tenaga laboratorium maka dari hasil yang diperoleh dapat dilihat bahwa para peserta dapat memahami materi yang diberikan dengan cepat.

Pada akhir pelatihan, pelaksana kegiatan memberikan formulir evaluasi kegiatan. Sebagian besar peserta (83 \%) menilai bahwa pelaksanaan pelatihan ini baik hingga sangat baik. Disamping itu, peserta menilai bahwa harapan mereka terhadap pelaksanaan pelatihan ini sesuai hingga sangat sesuai (82\%) dengan harapannya awalnya. Semua peserta juga berpendapat bahwa hasil pelatihan ini sangat bermanfaat untuk kegiatan instansi mereka di masa mendatang. Seluruh peserta berharap diadakannya pelatihan lanjutan penyusunan dokumen dan audit mutu.

\section{Simpulan Dan Saran}

Berdasarkan identifikasi dan perumasan masalah, tujuan kegiatan, serta dari hasil dan pembahasan dapat disimpulkan bahwa: 1) Pelatihan sistem manajemen mutu laboratorium (ISO 17025) dapat meningkatkan pemahama, wawasan, dan pengalaman peserta, 2) Pelatihan sistem manajemen mutu laboratorium (ISO 17025) dapat membantu peserta untuk melakukan gap analisis antara kondisi yang ada di laboratoriumnya saat ini dengan tuntutan persyarata ISO 17025, dan 3) Pelatihan sistem manajemen mutu laboratorium (ISO 17025) dapat melengkapi kompetensi peserta sebagai tenaga laboratorium pengujian. 


\section{Daftar Pustaka}

BSN. 2008. SNI ISO/IEC 17025. Persyaratan Umum Kompetensi Laboratorium Pengujian dan Laboratorium Kalibrasi. Badan Standarisasi Nasional.

Donnell, R., Christian, Jr., and Drilling, S. 2010. Implementing Quality in Laboratory Policies and Processes. CRC Press Taylor \& Francis Group. USA.

Hadi, H. 2007. Pemahaman dan Penerapan ISO/IEC 17025: 2005. Gramedia Pustaka Utama

Hibbert, D.B. 2007. Quality Assurance for the Analytical Chemistry Laboratory. Oxford University Press, Inc. New York.

Huber, 2009. Understanding and Implementing ISO/IEC 17025. Agilent Technologies, Inc. USA.

Juran, J.M and Godfrey, A.B. 1999. Juran's Quality Handbook. Fifth Edition. McGraw-Hill

Schlickman, J. 2003. ISO 9001:2000 Quality Management System Design. Artech House, Inc.

UNIDO. 2009. Complying with ISO 17025: A practical guidebook for meeting the requirements of laboratory accreditation schemes based on ISO 17025:2005 or equivalent national standards. united nations industrial development organization. Vienna.. 